Penelitian

\title{
Aktivitas Diuretik dan Analisa Mineral Urin Perlakuan Ekstrak Tanaman Kumis Kucing (Orthosiphon Stamineus Benth) pada Tikus Jantan
}

\author{
The Diuretic Activity and Urin Mineral Analysis of Cat Wishker's Extract \\ (Orthosiphon stamuneus Benth) Effect in Male Rats
}

\author{
Rini Madyastuti', letje Wientarsih', Setyo Widodo', Erni H Purwaningsih², Eva Harlina' \\ ${ }^{1}$ Departemen Klinik, Reproduksi, dan Patologi, Fakultas Kedokteran Hewan, \\ Institut Pertanian Bogor, Jawa Barat \\ ${ }^{2}$ Departemen Farmasi Kedokteran, Fakultas Kedokteran Umum, \\ Universitas Indonesia, Jakarta \\ *Penulis untuk korespondensi: rinipurwono@gmail.com \\ Diterima 16 Januari 2020, Disetujui 2 Juni 2020
}

\begin{abstract}
ABSTRAK
Tanaman Kumis Kucing merupakan salah satu tanaman yang memiliki banyak keuntungan dan sudah digunakan sejak dahulu dalam upaya menjaga kesehatan. Tujuan dari penelitian ini adalah mengevaluasi aktivitas diuretik dari penggunaan ekstrak Kumis Kucing dan mengukur kadar kalium dan natrium dalam urin. Sebanyak 24 ekor tikus dibagi menjadi empat grup; kontrol negatif (akuades), kontrol positif (furosemide), dosis ekstrak 1 (250mg/kg BB) dan dosis ekstrak 2 (500mg/kg BB). Ekstrak diberikan secara peroral selama 7 hari. Aktivitas diuretik pada kelompok ekstrak dan kontrol positif pada jam pertama $(P>0.05)$ dan jam keenam $(P<0.05)$. Volume urin kumulatif dosis 1 mendekati furosemide. Pengukuran mineral urin menunjukkan hasil kehilangan mineral natrium dan kalium pada kelompok ekstrak lebih kecil dibandingkan kelompok referensi. Hasil dari penelitian ini menunjukkan bahwa dosis efektif ekstrak Kumis Kucing adalah $250 \mathrm{mg} / \mathrm{kg}$ BB pada jam ke-2 dan menunjukkan kehilangan mineral dalam urinyang lebih kecil

Kata kunci: ekstrak kumis kucing, aktivitas diuretik, kalium, pH, natrium
\end{abstract}

\begin{abstract}
The cat whisker's is a medicinal plants with various benefit and had been used in years for maintaining the healthy. The aim of this research is to evaluate the diuretic activity of cat wishker's plant and the level of potassium and sodium in urine. Twenty four rats were divided into four groups; negative control (Aquadest), positive control (Furosemide), dose 1 ( $250 \mathrm{mg} / \mathrm{kg} \mathrm{BW}$ ) and dose 2 ( $500 \mathrm{mg} / \mathrm{kg} \mathrm{BW}$ ) cat wishker's leaf extract. The extract was administered by orally for seven days. Diuretic activity of extract and positive group at first hour $(\mathrm{P}>0.05)$ and at sixth hour $(\mathrm{P}<0.05)$. The cumulative urin volume of dose 1 extract as high nearly with furosemide. Mineral assay in urine showed that the lost of mineral sodium and pottasium at group extract was less than the reference. The result of this study showed that the effective dose of cat wishker's leaf extract can be used as diuretic was dose $250 \mathrm{mg} / \mathrm{kg} \mathrm{BW}$ at second hours and showed less mineral excreted by urin.
\end{abstract}

Keywords: cat wishker's leaf extract, diuretic activity, potassium, pH, sodium 


\section{PENDAHULUAN}

Pemanfaatan tanaman sebagai obat tradisional sudah digunakan sejak lama oleh masyarakat di Indonesia. Upaya pengembangan obat tradisional semakin ditingkatkan dengan dilakukannya penelitian dan pengujian terhadap kandungan kimia, keamanan penggunaan, dan aktivitas farmakologisnya. Indonesia memiliki keanekaragaman hayati berlimpah dan memiliki tanaman obat sebanyak 9600 jenis (Depkes 2007). Kelebihan dari obat yang berasal dari tanaman adalah aman dikonsumsi, efektif menyembuhkan penyakit, mekanisme sinergis, mudah didapat, dan harganya terjangkau (Permadi 2002).

Salah satu tanaman yang digunakan sebagai obat adalah tanaman kumis kucing. Kumis kucing (Orthosiphon stamineus Benth) berkhasiat untuk menghancurkan batu ginjal, melancarkan pengeluaran urin, mengurangi proses radang kandung kemih, dan menurunkan kadar glukosa darah. Aktivitas farmakologi dari tanaman ini disebabkan adanya senyawa metabolit sekunder seperti; ortosiphon, sinensetin, saponin, dan garam alkali terutama kalium(0.6-3.5\%) (Kardinan dan Ruhnayat 2003). Tanaman kumis kucing juga mengandung senyawa flavonoid (Olah et al. 2003) yang mempunyai aktivitas biologis sebagai diuretik (Zhong et al. 2012).

Agen diuretik merupakan zat yang dapat meningkatkan pengeluaran urin dan bekerja langsung terhadap ginjal. Beberapa sediaan diuretikum sintetis yang banyak digunakan yaitu furosemide dan spironolakton. Sediaan diuretikum dapat digunakan pada beberapa kasus klinis seperti sirosis hati, asites, sindrom nefritis, dan toksemia gagal ginjal (Agunu et al. 2005). Penggunaannya furosemid jangka panjang dapat menyebabkan ketidakseimbangan elektrolit, perubahan meta-bolisme, onset diabetes, aktivasi renin-angiotensi dan neuroendokrin sistem serta masalah seksual.

Penelitian dan pemanfaatan tanaman obat yang berkhasiat sebagai diuretik merupakan salah satu prioritas dalam pengembangan dan pemanfaatan tanaman obat di Indonesia sehingga obat diuretik menjadi sangat dibutuhkan (Sondang et al. 2014). Sepanjang pengetahuan peneliti, belum banyak dilakukan penelitian mengenai efek diuretik tanaman kumis kucing. Pengujian kualitas urin dengan parameter volume, in deks aktivitas diuretik, $\mathrm{pH}$, dan kadar mineral urin perlu dilakukan. Adanya datadata parameter tersebut menjadi penting untuk mengetahui efek pemberian ekstrak kumis kucing terhadap keseimbangan mineral dan prediksi mekanismenya.
Tujuan penelitian ini adalah untuk mengetahui aktivitas diuretik dan kandungan mineral dalam urin setelah pemberian ekstrak tanaman kumis kucing serta menentukan dosis yang efektif sebagai diuretik dan pengaruhnya terhadap keseimbangan mineral.

Penelitian ini diharapkan mampu memberikan informasi kepada masyarakat mengenai potensi daun kumis kucing sebagai diuretik melalui kajian analisis kualitas urin (volume, indeks aktivitas diuretik, $\mathrm{pH}$, kadar natrium, dan kalium) serta penggunaan dosis yang efektif sebagai diuretik.

\section{BAHAN DAN METODE}

Bahan yang digunakan pada penelitian ini adalah ekstrak tanaman kumis kucing yang dilarutkan dalam Gom Arab 5\%, tikus jantan galur Sprague dawley sebanyak 24 ekor berumur 3-4 bulan dengan bobot badan rata rata 200-300 gram, aquades, Gom Arab (PT Bratachem), dan Furosemid (Sediaan generik PT Kimia Farma). Simplisia serbuk tanaman Kumis Kucing diperoleh dari Balai Penelitian Tanaman Rempah dan Obat (BALITTRO) Bogor.

Penelitian ini telah memperoleh ijin dari komisi etik Lembaga Penelitian dan Pengabdian Kepada Masyarakat IPB dengan nomor: 115 - 2018 IPB pada tanggal 31 Agustus 2018.

\section{Analisis kualitatif fitokimia ekstrak}

Analisis kualitatif kandungan metabolit sekunder dalam ekstrak kumis kucing dilakukan dengan metode penapisan fitokimia menggunakan pereaksi uji alkaloid, terpenoid, saponin, tanin, fenolik dan flavonoid. Ekstrak etanol dibuat dengan metode maserasi dengan pelarut etanol $70 \%$ dan dipekatkan dengan menggunakan rotaryevaporator. Penapisan fitokimia dilakukan berdasarkan metode Harborne (1987).

\section{Analisis kuantitatif flavonoid dan fenolik ekstrak}

Penentuan total flavonoid berdasarkan metode Chang et al. (2002). Penentuan total flavonoid ini menggunakan metode kolorimetri dengan pereaksi aluminium klorida $\left(\mathrm{AlCl}_{3}\right)$ dan kuersetin digunakan sebagai standar flavonoid. Penentuan total fenol dilakukan dengan mengadaptasi metode dari Mc Donald et al (2001) dengan menggunakan pereaksi Foli-Ciocalteu dan gallic acid sebagai standar fenol. Total senyawa fenol dinyatakan sebagai gallic acid equivalent ( $\mathrm{GAE}$ ) dalam $\mathrm{mg} / \mathrm{g}$ bobot kering sampel berdasarkan kurva baku gallic acid. 


\section{Pengujian efek diuretik ekstrak}

Larutan ekstrak tanaman kumis kucing dan furosemid dibuat dalam sediaan suspensi dengan menggunakan gom arab sebagai suspending agent.

Tikus hewan coba dipuasakan kurang lebih 10-12 jam dengan tetap diberi minum ad libitum. Tikus dibagi menjadi 4 kelompok dan setiap tikus diberikan akuades sebanyak $10 \mathrm{ml} / 100$ gram dengan suhu $70^{\circ} \mathrm{C}$ sebagai loading dose peroral. Setelah 30 menit setiap tikus diberi perlakuan sesuai kelompoknya dengan dosis pemberian $1 \mathrm{~mL}$ per tikus. Tikus kemudian ditempatkan di kandang metabolik individual dan volume urin yang diekskresikan ditampung dan dilakukan pengukuran volume setiap jam selama 6 jam. Setelah itu dilanjutkan pengukuran volume urin kumulatif, pengukuran kadar natrium ( $\mathrm{Na}$ ), Kalium(K), dan pH. Hewan coba diberikan perlakuan ekstrak kumis kucing selama 7 hari dengan pemberian sehari sekali .

\section{Desain penelitian}

Sebanyak 24 ekor hewan coba dibagi ke dalam 4 kelompok yang terdiri dari 6 ekor tikus putih. Tabel pembagian kelompok dapat dilihat pada Tabel 1 .

\section{Pengukuran nilai pH, Kadar Natrium, dan Kalium}

Penetapan nilai $\mathrm{pH}$ urin dilakukan dengan menggunakan $\mathrm{pH}$ meter dengan kondisi urin harus segar supaya tidak terjadi pembentukan amonia oleh perombakan ureum. Pengukuran $\mathrm{pH}$ urin dilakukan setiap hari sebanyak dua kali pada setiap kelompok perlakuan.
Penentuan kadar natrium dan kalium dilakukan dengan preparasi urin di Laboratorium Ternak Perah, Fakultas Peternakan dan perhitungannya dilakukan dengan alat Spektrofotometer Serapan Atom di Departemen Kimia, Institut Pertanian Bogor.

\section{Analisis Data}

Pengukuran volume urin yang diperoleh digunakan untuk menghitung Indeks Aktivitas Diuretik (IAD) berdasarkan persamaan berikut.

\section{$I A D=\frac{\text { Volume urin kelompok bahan uji }}{\text { Volume urin kelompok kontrol negatif }}$}

Selain itu, urin kumulatif yang diperoleh dianalisis dengan menggunakan SPSS 17.0 dengan metode Analysis of Variance (ANOVA) pada tingkat kepercayaan 95\% dengan uji lanjut yaitu uji Duncan Multiple Range Test (DMRT). Perhitungan dan pengolahan data volume, indeks aktivitas diuretik, $\mathrm{pH}$, kadar natrium, dan kalium dilakukan dengan menggunakan Microsoft Excel.

\section{HASIL}

\section{Analisa kualitatif kandungan ekstrak kumis kucing}

Analisa kandungan metabolit sekunder ekstrak kumis kucing dengan metode penapisan fitokimia disajikan pada Tabel 2. Berdasarkan hasil uji fitokimia ekstrak tanaman kumis kucing mengandung metabolit sekunder flavonoid, fenolik, saponin, dan tanin. Beberapa metabolit sekunder lainnya seperti

Tabel 1 Pembagian kelompok uji aktivitas diuretik ekstrak kumis kucing

\begin{tabular}{cll}
\hline No & Kelompok & Perlakuan \\
\hline 1 & Kontrol Negatif(-) & akuades \\
2 & Kontrol Positif $(+)$ & furosemid $1,8 \mathrm{mg} / \mathrm{kg} \mathrm{BB}$ \\
3 & Ekstrak kumis kucing dosis 1 & ekstrak kumis kucing dosis 250 mg/kg BB \\
4 & Ekstrak kumis kucing dosis 2 & ekstrak kumis kucing dosis $500 \mathrm{mg} / \mathrm{kg} \mathrm{BB}$ \\
\hline
\end{tabular}

Tabel 2 Hasil uji fitokimia

\begin{tabular}{lcc}
\hline Uji fitokimia & Ekstrak tanaman kumis kucing \\
\hline Alkaloid & - \\
Flavonoid & + \\
Fenolik & + \\
Saponin & + \\
Tanin & + \\
Steroid & - \\
Triterpenoid & - \\
\hline
\end{tabular}

Keterangan : $(+)=$ mengandung $\quad(-)=$ tidak mengandung 
alkaloid, steroid, dan triterpenoid tidak terlihat pada pengujian kualitatif ini. Hasil positif diperoleh dari pengamatan deksriptif metabolit sekunder yang ditandai dengan perubahan warna pereaksi.

\section{Analisis kuantitatif flavonoid dan fenolik ekstrak}

Analisa kuantitatif total flavonoid dan fenolik ekstrak tanaman kumis kucing menunjukkan hasil total flavonoid sebesar $0.58 \mathrm{mg} / \mathrm{g}$ dan total fenolik sebesar $6.72 \mathrm{mg} / \mathrm{g}$. Hasil ini menunjukkan senyawa metabolit sekunder total fenolik lebih tinggi dibandingkan total flavonoid.

\section{Uji Diuretikum}

Rataan volume urin setiap jam selama 6 jam pengukuran pada setiap kelompok perlakuan disajikan dalam Tabel 3. Hasil pada Tabel 3, menunjukan bahwa setiap perlakuan mengalami peningkatan volume urin dari jam ke-1 sampai jam ke-3 kecuali pada kelompok ekstrak dosis 1 yang hanya mengalami peningkatan dari jam ke-1 sampai jam ke2 dan menurun pada jam ke-3. Kelompok kontrol positif meningkat dari jam ke-1 sampai jam ke-3. Volume tertinggi pada jamke- 6 terdapat perbedaan yang nyata dengan kelompok ekstrak $(P<0.05)$. Total volume urin selama 6 jam pengukuran pada perlakuan dosis 1 lebih besar dibandingkan perlakuan dosis 2.

\section{Indeks Aktivitas Diuretik}

Indeks aktivitas diuretik setiap jam selama 6 jam pada setiap perlakuan disajikan pada Tabel 4. Hasil perhitungan indeks aktivitas diuretik diperoleh data yang menunjukan bahwa furosemide sebagi kontrol positif memiliki indeks aktivitas diuretik terkuat pada jam ke-1 dan ke-2. Indeks aktivitas diuretik ekstrak daun kumis kucing dengan dosis 2 lebih rendah dibanding dengan dosis 1 .

\section{Nilai pH Urin}

Nilai rataan pH urin kumulatif setiap jam selama 6 jam pada setiap kelompok disajikan pada Tabel 5. Setiap kelompok perlakuan memiliki nilai $\mathrm{pH}$ urin tidak lebih dari 7 yang menunjukan bahwa nilai $\mathrm{pH}$

Tabel 3 Rataan volume urin $(\mathrm{mL})$ kumulatif dari tikus percobaan setiap jam

\begin{tabular}{ccccc}
\hline \multirow{2}{*}{ Jam ke- } & \multicolumn{4}{c}{ Volume urin $(\mathrm{mL})$ kumulatif pada kelompok } \\
\cline { 2 - 5 } & $\begin{array}{c}\text { Kontrol (-) } \\
\text { (Akuades) }\end{array}$ & $\begin{array}{c}\text { Kontrol }(+) \\
\text { (Furosemid) }\end{array}$ & $\begin{array}{c}\text { Kumis kucing Dosis 1 } \\
\text { Kumis kucing } \\
\text { Dosis 2 }\end{array}$ \\
\hline 1 & $0.40 \pm 0.74^{\mathrm{a}}$ & $1.49 \pm 1.22^{\mathrm{a}}$ & $1.24 \pm 1.91^{\mathrm{a}}$ & $0.70 \pm 0.96^{\mathrm{a}}$ \\
2 & $0.54 \pm 1.44^{\mathrm{a}}$ & $2.00 \pm 1.65^{\mathrm{a}}$ & $2.57 \pm 3.58^{\mathrm{a}}$ & $1.11 \pm 1.03^{\mathrm{a}}$ \\
3 & $1.94 \pm 1.52^{\mathrm{a}}$ & $3.12 \pm 2.77^{\mathrm{a}}$ & $1.13 \pm 1.34^{\mathrm{a}}$ & $2.29 \pm 2.21^{\mathrm{a}}$ \\
4 & $2.63 \pm 1.97^{\mathrm{a}}$ & $2.30 \pm 2.22^{\mathrm{a}}$ & $3.17 \pm 2.81^{\mathrm{a}}$ & $2.71 \pm 1.38^{\mathrm{a}}$ \\
5 & $0.89 \pm 1.16^{\mathrm{a}}$ & $2.52 \pm 2.94^{\mathrm{a}}$ & $3.23 \pm 2.65^{\mathrm{a}}$ & $1.69 \pm 1.48^{\mathrm{a}}$ \\
6 & $1.51 \pm 0.95^{\mathrm{a}}$ & $4.47 \pm 2.71^{\mathrm{b}}$ & $1.64 \pm 1.44^{\mathrm{a}}$ & $1.29 \pm 0.34^{\mathrm{a}}$ \\
\hline Total & $7.91 \pm 0.44$ & $13.90 \pm 0.69$ & $12.98 \pm 0.88$ & $9.79 \pm 0.62$ \\
\hline
\end{tabular}

Keterangan : huruf superscript yang sama dalam kolom yang sama menunjukan tidak ada perbedaan yang nyata ( $\mathrm{p}>0.05$ )

Tabel 4 Hasil perhitungan indeks aktivitas diuretik dari tikus percobaan setiap jam perlakuan

\begin{tabular}{ccccc}
\hline \multirow{2}{*}{ Jam ke- } & \multicolumn{4}{c}{ Indeks Aktivitas Diuretik (IAD) pada kelompok } \\
\cline { 2 - 5 } & Kontrol (-) & Kontrol (+) & $\begin{array}{c}\text { Kumis kucing } \\
\text { Dosis 1 }\end{array}$ & $\begin{array}{c}\text { Kumis kucing } \\
\text { Dosis 2 }\end{array}$ \\
\hline 1 & - & 3.72 & 3.11 & 1.75 \\
2 & - & 3.70 & 4.76 & 2.05 \\
3 & - & 1.66 & 0.58 & 1.18 \\
4 & - & 0.87 & 1.20 & 1.03 \\
5 & - & 0.87 & 3.63 & 1.89 \\
6 & - & 2.96 & 1.09 & 0.85 \\
\hline
\end{tabular}


urin semua kelompok masih batas normal dalam rentang 7-3-8. Perlakuan ekstrak tidak memberikan perubahan $\mathrm{pH}$ pada urin.

\section{Kadar Natrium dan Kalium}

Kadar natrium dan kalium urin tikus pada hari awal (hari ke-1) dan hari akhir (hari ke-7) setiap kelompok perlakuan disajikan pada Tabel 6 . Nilai hasil pengukuran kadar natrium dan kalium urin pada hari akhir (hari ke-7) terjadi perubahan yaitu mengalami peningkatan pada semua kelompok perlakuan dibandingkan kontrol negatif atau normal. Kelompok kontrol positif menunjukan peningkatan paling tinggi. Kelompok yang diberi ekstrak tanaman kumis kucing mengalami peningkatan walaupun tidak sebesar kontrol positif. Kadar natrium pada kelompok perlakuan dosis 2 lebih tinggi dibandingkan dosis 1 , hal yang sama juga terlihat pada kadar kalium.

\section{PEMBAHASAN}

Tanaman Kumis Kucing (Orthosiphon aristatus Blume) merupakan salah satu tanaman yang mudah ditemui dan memiliki aktivitas diuretik. Beberapa penelitian sebelumnya telah melakukan pengujian ekstrak kumis kucing sebagai antioksidan (Akowuah et al. 2004), anti inflamasi (Laavola et al. 2012), dan antilitiasis (Zhong et al. 2012). Senyawa metabolit sekunder penandaatau marker dari tanaman iniadalah sinensetin (Depkes, 2008), sedangkan kandungan senyawa turunan flavonoid yang lain antara lain yaitu eupatorin, 3 - hydroxy-5,6,7,4-tetrametoksi flavon, rosmarinic acid dan cichoric acid (Zhong et al.2012). Perlakuan ekstrak tanaman kumis kucing menghasilkan volume urin diatas normal karena adanya flavonoid(Olah et al. 2003). Selain flavonoid, senyawa metabolit sekunder yang berperan terhadap aktivitas diuretik adalah polifenol dan saponin (Maghrani et al. 2005). Flavonoid dan fenolik termasuk ke dalam senyawa polifenol.

Berdasarkan hasil analisa kualitatif dan kuantitatif menunjukkan ekstrak tanaman kumis kucing mengandung flavonoid, saponin dan fenolik. Mekanisme diuretikum dari metabolit sekunder ini adalah flavonoid mampu meningkatkan laju filtrasi glomerulus sehingga terjadi peningkatan volume urin (Jouad et al. 2011 dan Madyastuti et al. 2015), stimulasi aliran darah regional atau inisial vasodilatasi (Stanic dan Samarzija, 1993) dan menghambat reabsorpsi air dan ion pada daerah tubulus (Pantoja et al. 1991).

Beberapa penelitian sebelumnya yang mengevaluasi aktivitas diuretik dari ekstrak herbal medicine menyatakan mekanisme lain dari flavonoid selain yang disampaikan diatas. Flavonoid berperan dalam menstimulasi pelepasan renal prostaglandin (Gasparotto et al. 2009). Mekanisme yang lain disampaikan yaitu meningkatkan aktivitas pembentukan prostasiklin (Schramm et al. 2001). Aktivitas diuretik dari ekstrak kumis kucing menunjukkan waktu kinetika pada jam ke 3 dan 4 sementara dibandingkan sediaan furosemid onset pada 1 jam pertama dan memiliki durasi kerja selama 6 jam.

Diuresis terjadi karena adanya peran mekanisme nitrit oksida (NO) dan prostaglandin secara sistemik dan mengatur tone arteriol serta tekanan darah. Pada organ ginjal berperan dalam meregulasi dilatasi aferen arteriol dan laju filtrasi glomerulus (Chappell 2012). Flavonoid dan turunannya merupakan

Tabel 5 Nilai rataan $\mathrm{pH}$ urin

\begin{tabular}{cccc}
\hline & $\mathrm{pH}$ urin Kelompok & Kumis kucing dosis 2 \\
\hline Kontrol $(-)$ & Kontrol $(+)$ & $\begin{array}{c}\text { Kumis kucing } \\
\text { dosis } 1\end{array}$ & $7.18 \pm 0.05$ \\
\hline $7.14 \pm 0.10$ & $7.15 \pm 0.05$ & $7.26 \pm 0.04$ \\
\hline
\end{tabular}

Tabel 6 Kadar Natrium dan Kalium (ppm) urin tikus setiap kelompok perlakuan

\begin{tabular}{lccc}
\hline \multicolumn{1}{c}{ Kelompok } & Kadar Natrium & Kadar Kalium & Rasio Na/K \\
\hline Kontrol (-) & 731.22 & 867.97 & 0.84 \\
Kontrol $(+)$ & 1892.99 & 3728.06 & 0.55 \\
Kumis Kucing dosis1 & 1134.55 & 1315.44 & 0.86 \\
Kumis Kucing dosis 2 & 1365.50 & 2561.30 & 0.53 \\
\hline
\end{tabular}


senyawa yang berperan dalam mengaktivasi reseptor bradikinin $\mathrm{B}_{2}$ dan reseptor muskarinik yang selanjutnya menstimulasi pelepasan NO dan prostaglandin (Prando et al. 2016).

Pada penelitian dengan menggunakan herbal, kenaikan dosis belum tentu bersamaan kenaikan output volume urin karena berkaitan dengan jumlah reseptor dan kandungan metabolit sekunder. Hal tersebut menunjukkan bahwa beberapa tanaman memiliki ambang batas dosis yang mampu memberikan khasiat sehingga mengkonsumsi tanaman herbal dengan jumlah yang banyak tanpa mempertimbangkan dosis efektif tidak akan memberikan manfaat yang diinginkan tetapi dapat membahayakan tubuh (Duryatmo 2003). hal ini sesuai dengan penelitian ini, perlakuan dosis 1 menunjukkan akumulasi volume urin yang lebih besar dibandingkan perlakuan dosis 2. Volume urin pada kelompok kontrol negatif sebagai kotrol normal sesuai dengan Lingga et al. 2014, yang menyatakan akumulasi urin selama 6 jam kurang lebih sebanyak $7 \mathrm{~mL}$.

Menurut Asif et al. 2013, sediaan ekstrak dinyatakan kuat jika menunjukkan nilai indeks diuretik diatas 1.5 dan diuretik sedang jika kurang dari 1.5 . penelitian ini pada kelompok kontrol positif dan perlakuan dosis 1 menunjukkan aktivitas diuretik kuat, sedangkan perlakuan dosis 2 termasuk ke dalam indeks diuretik menengah.

Nilai $\mathrm{pH}$ urin normal tikus berkisar antara 7.3 sampai 8 . Nilai $\mathrm{pH}$ urin ditentukan oleh pengaturan asam dan basa di ginjal. Sejumlah $\mathrm{HCO}_{3}^{-}$yang difiltrasi terus menerus ke dalam tubulus ginjal dan diekskresikan ke dalam urin akan menyebabkan urin bersifat basa. Sebaliknya, sejumlah ion $\mathrm{H}^{+}$yang difiltrasi secara terus-menerus ke dalam tubulus ginjal dan diekskresikan ke dalam urin akan menyebabkan urin bersifat asam. Pengaturan konsentrasi ion $\mathrm{H}^{+}$, ginjal mensekresikan ion $\mathrm{H}^{+}$ke tubulus, mereabsorpsi ion $\mathrm{HCO}_{3}^{-}$, dan memproduksi $\mathrm{HCO}_{3}^{-}$yang baru untuk mengurangi dan menetralisir kelebihan ion $\mathrm{H}^{+}$di dalam tubuh (Nalwaya et al. 2009)

Penggunaan furosemid dapat menimbulkan efek samping gangguan keseimbangan cairan dan elektrolit terutama natrium dan kalium. Kedua ion tersebut banyak diekskresikan sehingga menimbulkan hiponatremia dan hipokalemia (Erlina et al. 2006). Pemberian ekstrak mampu memodulasi pengeluaran mineral natrium dan kalium dalam urin agar tidak banyak dieskresikan. Peningkatan ekskresi ion natrium dan kalium melalui urin yang terus menerus dapat mengakibatkan gangguan homeostasis ion di dalam tubuh, dehidrasi ion, danpada kondisi kronis dapat mengganggu kerja jantung (Bipat et al. 2008).

Hasil pengukuran pada kelompok ekstrak, ekskresi ion kalium lebih tinggi dibandingkan natrium sehingga termasuk diuretik kaliuretik (Montejano-Rodriguez et al. 2013). Rasio perhitungan pada dosis rendah menunjukkan hampir mendekati 1 artinya ekskresi ion natrium dan kalium hampir seimbang rasionya. Kadar natrium yang rendah dan kadar kalium yang tinggi menunjukan mekanisme kerja diuretik di lengkung henle. Diuretik lengkung henle bekerja dengan merintangi transport $\mathrm{Cl}^{-}$sehingga terjadi peningkatan reabsorpsi $\mathrm{Na}^{+}$, pengeluaran $\mathrm{K}^{+}$, dan air dalam urin (Tjay dan Rahardja 2002).

Kesimpulan dari penelitian ini adalah ekstrak tanaman kumis kucing memiliki aktivitas diuretik dan mampu memodulasi ekskresi ion natrium dan kalium dalam urin. Adanya senyawa flavonoid, saponin dan fenolik yang berperan terhadap aktivitas diuresis. Dosis paling efektif ditunjukkan oleh dosis $250 \mathrm{mg} / \mathrm{kg} \mathrm{BB}$.

"Penulis menyatakan tidak ada konflik kepentingan dengan pihak-pihak yang terkait dalam penelitian ini".

\section{DAFTAR PUSTAKA}

Agunu A, Abdurahman EM, Andrew GO, Muhammed Z. 2005. Diuretic activity of the stem-bark extract of steganotaenia araliaceahoehst. Journal of Ethnopharmacology. 96: 1-5.

Akowuah GA, Zhari I, Norhayati I, Sadikun A. 2004. Radical scavenging activity of methanol leaf extracts of Orthosiphon stamineus. Pharmaceutical Biology 42(8):629-35.

Asif M, Atif M, Malik ASA, Dan ZC, Ahmad I, Ahmad A. 2013. Diuretic activity of Trianthema portulacastrum crude extract in albino rats. Tropical Journal of Pharmaceutical Research 12(6): $967-72$.

Bipat R, Toelsie JR, Joemmanbaks RF, Gummels JM, Klaverweide J, Jhanjan N, Orie S, Ramjiawan K, Van Brussel A, Soekhoe RC, Mans DRA. 2008. Effects of plants populary used against hypertension on nornephineprine-stimulated guinea pig atria. Pharmacognosy. 4(13):12-9.

Chappell MC. 2012. Nonclassical renin angiotension system and renal function. Compr Physiol. 2(4):2733-2752. 
Chang C, Yang M, Wen H, Chern J. 2002. Estimation of total flavonoid content in propolis by two complementary colorimetric methods. Journal Food and Drug Analysis 10:178-82.

[Depkes] Departemen Kesehatan. 2008. Farmakope Herbal Indonesia. Edisi I. Jakarta: Departemen Kesehatan RI.

[Depkes] Departemen Kesehatan. 2007. Kebijakan Obat Tradisional Nasional. Jakarta (ID): Departemen Kesehatan RI.

Duryatmo S. 2003. Aneka Ramuan Berkhasiat dari Temu-Temuan Temukan Rahasia Kesehatan dari Alam. Jakarta (ID): Pustaka Pembangunan Swadaya Nusantara.

Erlina FB, Imelda EP, Andani, Rustam. 2006. Perbandingan efek diuretika serta kadar natrium dan kalium darah antara pemberian ekstrak etanol daun tempuyung dengan furosemida. Jurnal Sains dan Teknologi Farmasi 11:76-80.

Gasparotto JA, Boffo MA, Lourenco EL, Stefanello ME, Kassuya CAL, Marques MC.2009. Natriuretic and diuretic effects of Tropaeolum majus (Tropaeolaceae) in rats. Journal of Ethnopharmacology 122: 517- 522.

Gudjral ML, Saxena PN, Mishra SS. 1955. An experimental study of the comparative activity of indigenous diuretics. Journal of Indian Medical Association 25:49-51.

Guyton AC, Hall JE. 2006. Textbook of Medical Physiology. Edisi ke-11. Philadelphia: Elvesier inc

Harborne JB. 1987. Metode Fitokimia. Kosasih Padmawinata dan Iwang Soediro, penerjemah. Bandung (ID): Institut Teknologi Bandung.

Haryoto , Suhendi A, Prasnaparamita E, Sujono T, Muhtadi. 2015. Uji toksisitas subkronis ekstrak etanol daun tumbuhan sala (Cynometra ramiflora Linn) dengan parameter kimia urin dan histopatologi organ ginjal pada tikus galur wistar. The $2^{\text {nd }}$ University Research Coloqium. Surakarta (ID):Fakultas FarmasiUniversitas Muhammadiyah. Jouad H, Lacaille-Dubois M, Lyoussi B, Eddouks M. 2001. Effects of the flavonoids extracted from Spergularia purpurea Pers. on arterial blood pressure and renal function in normal and hipertensive rats. Journal of Ethnopharmacology. 76(2):159-63.

Kardinan A, Ruhnayat A. 2003. Budidaya Tanaman Obat Secara Organik. Jakarta (ID) : Agro Media Pustaka.

Kardiningsih. 2002. Identifikasi karakteristik biologis dari tikus penelitian "wistar deriverd-lembaga makanan rakyat strain" [Internet]. [diunduh 2018
Feb 14]. Tersedia pada: http://diligib.litbang. depkes.go.id.

Latuconsina NH, Fatimawali, Citraningtyas G. 2014. Uji efektivitas diuretik ekstrak etanol biji salak (Salacca zalaca varietas zalaca (gaert.) Voss) pada tikus putih jantan galur wistar (Rattus norvegicus). Jurnal Ilmiah Farmasi. Manado (ID) : Fakultas Matematika dan Ilmu Pengetahuan Alam UNSRAT. 3(3):179.

Laavola M, Nieminen R, Yam M, Sadikun A, Asmawi $M$, Basir R, et al. 2012. Flavonoids eupatorin and sinensetin present in Orthosiphon stamineus leaves inhibit inflammatory gene expression and STAT1 activation. Planta Medica 78(8):779-86. McDonald S, Prenzler PD, Autolovich M, Robards K. 2001. phenolic content and antioxidant activity of olive extracts. Food Chemistry $73: 73-84$.

Madyastuti R, Widodo S, Wientarsih I, Harlina E. 2015. Infusum daun alpukat sebagai inhibitor kristalisasi kalsium oksalat pada ginjal. Jurnal Veteriner 16(4): 525-532.

Maghrani M, Zeggwagh NA, Haloui M, Eddouks M. 2005. Acute diuretic effect of aqueous extract of Retama raetam in normal rats. Journal of Ethnopharmacology 99: 31-35.

Mary JM, Richard AH, Pamela CC. 1995. Farmakologi: Ulasan Bergambar. Jakarta (ID): Penerbit Widya Medika.

Montejano-Rodríguez JR, Almaguer-Vargas G, Gayosso-De-Lucio JA, Ocharan Hernández ME, Moreno Martínez RE, Hernández Caballero ME, et al. Evaluation of the diuretic activity of the ethanolic extract of Geranium seemannii Peyr. in Wistar rats. Journal of Pharmacy Research 6(7):709-13.

Nalwaya N.Jarald E. Asghra S. Showkat P. 2009 Diuretic activity of herbal product UNEX. International Journal of Green Pharmacy 3(3):224-226.

Nurihardiyanti, Yuliet, Ihwan. 2015. Aktivitas diuretik kombinasi ekstrak biji pepaya (Carica papaya L) dan biji salak (Salacca zalacca varietas zalacca (Gaert.)Voss) pada tikus jantan galur wistar (Rattus novergicus $L$ ). Journal of Pharmacy. Palu (ID): Fakultas Matematika dan Ilmu Pengetahuan Alam Universitas Tadulako. Vol.1 (2):106.

Olah NK, Radu L, Mogosan C, Hanganu D, Gocan S. 2003. Phytochemical and pharmacological studies on Orthosiphon stamineus Benth. (Lamiaceae) hydroalcoholic extracts. Journal of Pharmaceutical and Biomedical Analysis 33:117-123.

Pantoja CV, Chiang LC, Norris BC, Concha JB. 1991. Diuretic, natriuretic and hypotensive effects 
produced by Allium sativum (garlic) in anaesthetized dogs. Journal of Ethnopharmacology 31: 325-331.

Permadi A. 2002. Tanaman Obat Pelancar Air Seni. Jakarta (ID): Penebar Swadaya.

Prando TBL, Barboza LN, Araújo V de O, Gasparotto FM, de Souza LM, Lourenço ELB, et al. 2016. Involvement of bradykinin B2 and muscarinic receptors in the prolonged diuretic and antihypertensive properties of Echinodorus grandiflorus (Cham. \& Schltdl.) Micheli. Phytomedicine 23(11):1249-58.

Schramm DD, Wang JF, Holt RR, Ensunsa JL, Gonsalves JL, Lazarus SA, Schmitz HH, German JB, Keen CL. 2001. Chocolate procyanidins decrease the leukotriene-prostacyclin ratio in humans and human aortic endothelial cells. The American Journal of Clinical Nutrition 73: 36-40.

Sondang LI, Citraningtyas G, Astuti LW. 2014. Uji efek ekstrak etanol patikan kebo (Euphorbia hirta Linn.) sebagai diuretik pada tikus putih jantan galur wistar (Rattus Novergicus sp.). Jurnal Ilmiah Farmasi. Manado (ID): Fakultas Matematika dan Ilmu Pengetahuan Alam UNSRAT 3(3):290.
Stanic G, Samarzija I. 1993. Diuretic activity of Satureja montana subsp. Montana extracts and oil in rats. Phytotherapy Research 7:363-366.

Tjay dan Rahardja. 2002. Obat-obat Penting, Khasiat, Pengunaaan dan Efek Sampingnya Edisi V. Jakarta(ID) : PT Elex Media Komputindo Kelompok Gramedia.

Yam MF, Ang LF, Basir R, Salman IM, Ameer OZ, Asmawi MZ. 2009. Evaluation of the anti-pyretic potential of Orthosiphon stamineus Benth standardized extract. Inflammopharmacology. 17(1): 50-4.

Zhong Y, Yu C, Ying HZ, Wang ZY, Cai HF. 2012. Prophylactic effects of Orthosiphon stamineus Benth. extracts on experimental induction of calcium oxalate nephrolithiasis in rats. Journal Pharmaceutical and Biomedical Analysis 144(3): 761-67. Doi : 10.1016 /j.jep. 2012 . 09.052.

Zhu W, Xu Y, Feng Y, Peng B, Che J, Liu M, Zheng JH. 2014. Prophylactic effects of quercetin and hyperoside in a calcium oxalate stone forming rat model. Urolithiasis 42(6): 519-26. Doi 10.1007/s00240-014-0695-7. 